\title{
Sedimentary chydorid (Cladocera) ephippia in relation to lake ecological quality in the Austrian Alps
}

\author{
Liisa NEVALAINEN,,$^{1,2, *}$ Tomi P. LUOTO ${ }^{1,3}$ \\ ${ }^{1}$ Institute for Limnology, Austrian Academy of Sciences, Mondsee, Austria; ${ }^{2}$ Department of Environmental Sciences, University of \\ Helsinki, Finland; ${ }^{3}$ Department of Geosciences and Geography, University of Helsinki, Finland. \\ *Corresponding author: liisa.nevalainen@helsinki.fi
}

\begin{abstract}
Research on chydorid (Crustacea: Cladocera: Chydoridae) reproduction is scarce and very little is known about the dynamics of parthenogenetic (asexual) and gamogenetic (sexual) reproduction modes in these cyclical parthenogens. The paleolimnological approach has a lot to offer to this research since chydorid carapaces (indicative of asexual reproduction) and ephippia (indicative of sexual reproduction) are identifiable in lake sediments. In the current study, we examined historical changes in chydorid reproduction patterns in an Austrian Alpine lake with the objective to explore reproductive shifts under limnological variability and with the hypothesis that sexual reproduction intensifies under unfavourable environmental conditions. For this, we utilised subfossil remains from a sediment sequence covering the past 300 years in a high Alpine lake, lake Oberer Landschitzsee. The results suggested that in-lake processes likely changed as a response to post-Little Ice Age (LIA) climate warming. Indeed, the benthic quality - indicated by the chironomidbased benthic quality index (BQI) - deteriorated, and the productivity - indicated by organic matter in the sediment - increased. The chydorid community exhibited dramatic shifts in the post-LIA section of the core, around 1850-1950 AD, when the two dominant species Alona (A.) affinis and A. quadrangularis were outcompeted by Acroperus harpae, Alonella excisa, and Chydorus (C.) sphaericus-type and their reproduction gradually shifted towards the dominance of sexual reproduction. The community shift and prevalence of sexual reproduction coincided with the period of unfavourable limnological conditions, evidenced by low BQI values and higher organic content. Therefore, we suggest that the intensified sexual reproduction was a local response to deteriorated benthic conditions and a vigorous adaptive mechanism to ensure successful diapause and genetic variability under environmental change. The results give reason to suggest that fossil chydorid assemblages and ephippia indicate the ecological quality of lake ecosystems and, thus, they can be used as additional proxies in future assessments of the lake ecological status.
\end{abstract}

Key words: Alpine lakes, benthic quality, Chydoridae, diapause, environmental change, paleolimnology.

Received: May 2012. Accepted: July 2012.

\section{INTRODUCTION}

The pioneering work of David G. Frey on cladoceran sedimentary remains, particularly on chydorids (Chydoridae), laid the basis for integrating the paleoecological approach with neoecological research (Frey, 1960). Since then, subfossil remains of chydorids in surface sediments and in down-core sediment sequences have proven to be applicable for increasing knowledge on cladoceran taxa with respect to each other and their living environment. The paleoecological approach has been utilised in investigating chydorid ecology, for example distribution (Lotter et al., 1997, 1998; Bjerring et al., 2009; Brancelj et al., 2009), habitat affinities (Binford, 1986; Kattel et al., 2007; Nevalainen 2011, 2012), taxonomy (Frey, 1959, 1962; Sarmaja-Korjonen et al., 2000; Nevalainen et al., 2012b), and reproductive modes (Sarmaja-Korjonen, 2003; Kultti et al., 2011; Nevalainen et al., 2011b, 2011c).

Although the paleoecological approach on cladocerans put out findings often useful also for the neoecological research and especially for the environmental change ecology (Manca et al., 2007; Jeppesen et al., 2001, 2011), a vast unexploited gap between these two research traditions still exists. Unfortunately, the paleoecological approach is not very often used to test specific ecological theories or hypotheses in aquatic ecosystems (Smol, 1991). Rather, the emphasis has been given to the use of aquatic organisms as proxies for different environmental factors. There are some advantages of using the paleoecological approach in the research of cladoceran ecology, especially with chydorids. Firstly, the sampling and sample analysis is relatively easy and effective since subfossil assemblages in single sediment samples give indications of the lake-wide community (Frey, 1960; Rautio, 2007; Nevalainen, 2010). Secondly, the down-core sequences provide a true long-term temporal perspective on the community and population dynamics that cannot be achieved even through an exhaustive neoecological monitoring (Sayer et al., 2010).

Research on chydorid reproductive ecology is scarce and, thus, very little is known about the long-term dynam- 
ics between parthenogenetic and gamogenetic reproduction modes in these cyclical parthenogens. In chydorids, gamogenesis - leading to diapausal resting eggs - plays an important role for the survival through periods of environmental stress, dispersal, and genetic variance within populations (Frey, 1982). In general, it is hypothesised that climatic cues primarily induce sexual reproduction in chydorids (Shan and Frey, 1968; Shan, 1974; Kubersky, 1977). However, it has been also suggested that non-climatic environmental signals, such as toxic stress (Kiser et al., 1963), high predation pressure (Nevalainen, 2008), or oxygen availability (Nevalainen and Sarmaja-Korjonen, 2008) may interfere with the induction and intensity of sexual reproduction. As the intensity of gamogenesis determines the number of dormant resting eggs, the patterns in gamogenetic intensity are important for the success of diapause and survival of chydorid populations. As stated above, the paleoecological approach is useful for its long-term temporal views (Sayer et al., 2010) and chydorid parthenogenetic and gamogenetic remains preserve identifiable in lake sediments. Given this, the sedimentary archives of the remains of these two reproductive modes can be employed for detecting long-term dynamics in gamogenetic intensity (Sarmaja-Korjonen, 2003; Nevalainen et al., 2011b, 2011c).

In the current study, we aim to use sedimentary archives of benthic chydorids to infer past intensity in their sexual reproduction in an Alpine lake and compare these results to the lake ecological quality inferred from fossil Chironomidae assemblages. We hypothesise that under a period of unfavourable environmental conditions (i.e. low ecological quality) chydorids reproduce with high sexual intensity to produce high amount of dormant resting eggs for survival (i.e. diapause and genetic diversity). With this study, we also aim to provide evidence for the usability of microbenthic communities and their resting eggs in assessments of lake ecological quality.

\section{METHODS}

Lake Oberer Landschitzsee (area 8.8 ha, max. depth $13.6 \mathrm{~m}$ ) is located at the southern slope of the mountain range Niedere Tauern in the Eastern Alps of Austria (47 14 '52"N, 13 $51^{\circ}$ '40"E) (Fig. 1), at an altitude of 2076 $\mathrm{m}$ asl, slightly above the present tree line of Pinus cembra. It is the topmost basin of a chain of three lakes (Oberer, Mittlerer, and Unterer Landschitzsee). The basins are on crystalline bedrock with mica-schists and metamorphic carbonates. The basic limnological variables, measured with a multiparameter sonde 6600V2 (YSI inc., Yellow Springs, OH, USA) in summer 2010, indicated that the lake is currently oligotrophic and has good oxygen conditions during the summer. The limnological parameters as mean values from the entire water column (and hypolimnion) were as follows: dissolved oxygen $8.5 \mathrm{mg}$
$\mathrm{L}^{-1}$ (9.1), pH 7.4 units (6.8), conductivity $12.8 \mu \mathrm{S} \mathrm{cm}^{-1}$ (13.0), Chlorophyll a $1.5 \mathrm{mg} \mathrm{L}^{-1}$ (3.1), and total dissolved solids $0.008 \mathrm{~g} \mathrm{~L}^{-1}(0.009)$.

A short sediment core, consisting of fine detritus gyttja, was collected from a small boat with a Kajak gravity corer in July 2010 (Fig. 1). The water depth at the sampling point was $10.5 \mathrm{~m}$. The retrieved $16 \mathrm{~cm}$ sediment core was sliced into $1-\mathrm{cm}$ thick intervals in the field and the subsamples were stored in plastic bags at $+4^{\circ} \mathrm{C}$ in a cold room for later preparation.

The sediment core was dated using the radioactive isotope of lead ${ }^{210} \mathrm{~Pb}$ radiometric dating method. The dating was carried out in the Laboratory of Quaternary Geochronology at the Institute of Geological Sciences, Polish Academy of Sciences in Warsaw (Poland), where the time-depth model was also constructed. The ${ }^{210} \mathrm{~Pb}$ activity was determined indirectly via alpha-spectrometry measuring the isotope of polonium ${ }^{210} \mathrm{Po}(\alpha=5.31 \mathrm{MeV}$, $\mathrm{T} 1 / 2=138 \mathrm{~d}$ ) activity. As an internal yield tracer, the known amount of ${ }^{208}$ Po was added to the weighted sample. Polonium was separated from the sample using strong hydrochloric and nitric acid and was deposited on silver disks

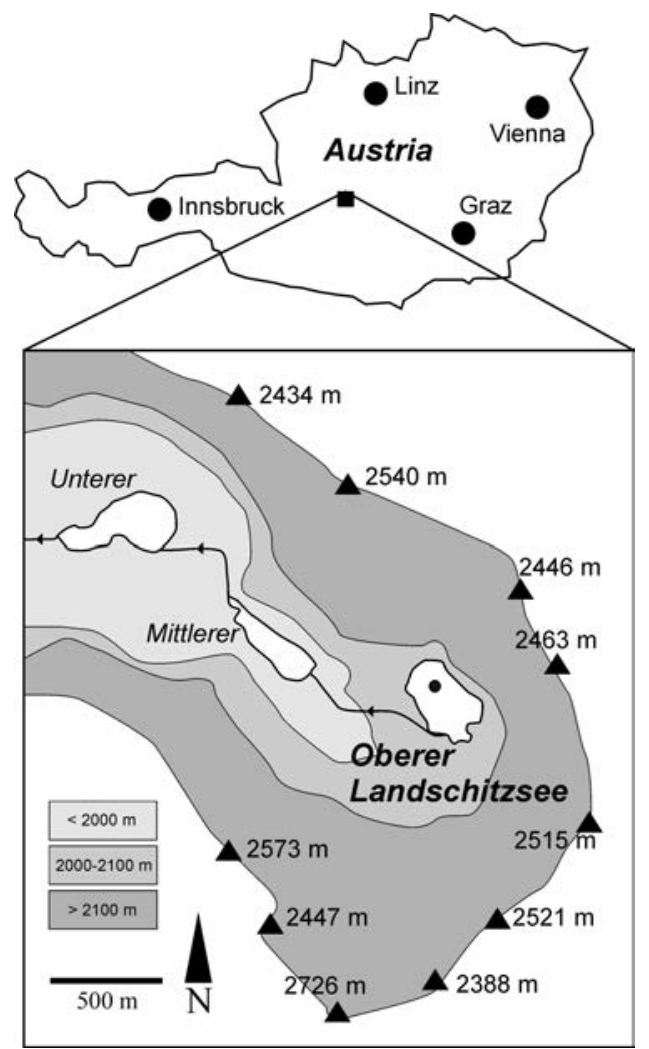

Fig. 1. Location and geographical settings of lake Oberer Landschitzsee $\left(47^{\circ} 14^{\prime} 52^{\prime}\right.$ 'N , $13^{\circ} 51^{\prime} 40^{\prime}$ 'E) in mountain range Niedere Tauern, Austria. 
(Flynn, 1968). The activity of ${ }^{210} \mathrm{Po}$ and ${ }^{208} \mathrm{Po}$ was measured using the OCTETE PC alpha spectrometer (ORTEC, Oak Ridge, TN, USA). To estimate the age of sediment subsamples (Fig. 2), the constant rate of unsupported ${ }^{210} \mathrm{~Pb}$ supply model (CRS) was used (Appleby, 2001). The activity of unsupported (allochthonous) ${ }^{210} \mathrm{~Pb}$ was calculated by subtracting the supported (autigenic) ${ }^{210} \mathrm{~Pb}$ activity. Supported ${ }^{210} \mathrm{~Pb}$ was determined by measuring old sediments containing no allochthonous ${ }^{210} \mathrm{~Pb}$ and assuming the constant activity of authigenic ${ }^{210} \mathrm{~Pb}$ along the sediment column. The age-depth function was calculated using a randomisation method and the curve was fitted using the LOESS procedure. No terrestrial macrofossils were found from the lower sediment sequence and radiocarbon analytics from bulk sediment samples were deemed inappropriate to date the lower sediment samples because of carbonate rocks in the catchment. Thus, age estimation of the lower parts of the sediment core was obtained through extrapolation (von Gunten et al., 2008).

The organic content and dry matter (DM) of the sediment was measured as loss-on-ignition (LOI) for environmental indications (i.e. productivity). Here, wet sediment samples $(10-12 \mathrm{~g})$ were first dried at $105^{\circ} \mathrm{C}$ for $12 \mathrm{~h}$ and then ignited in an oven at $550^{\circ} \mathrm{C}$ for $2 \mathrm{~h}$ (Dean, 1974). The organic content is expressed as percentages of DM $(\% \mathrm{DM})$.

The procedure for preparing the sediment samples for ephippium analysis followed the standard methods described in Szeroczyńska and Sarmaja-Korjonen (2007) and Sarmaja-Korjonen (2003, 2004). Known quantities (1-5 g) of wet sediment subsamples were carefully sieved through a $51-\mu \mathrm{m}$ mesh under running tap water; the residue in the sieve was concentrated by centrifuging it for $10 \mathrm{~min}$ at $4000 \mathrm{rpm}$ and afterwards dyed with a few drops of glycerol-safranine. A known volume of the samples were then mounted on microscopic slides and analysed for chydorid carapaces and ephippia under a light microscope with magnifications 100/200/400times. A minimum of 100 chydorid carapaces and ephippia were enumerated from the samples and identified following Szeroczyńska and Sarmaja-Korjonen (2007). The intensity of the two reproduction modes in the community was determined by calculating the relative abundances of carapaces (parthenogenesis) and ephippia (gamogenesis) from the sum of total carapaces+ephippia (Sarmaja-Korjonen 2003, 2004). Unfortunately, ephippia of Alona (A.) affinis and A. quadrangularis are extremely difficult to separate from each another (Szeroczyńska and Sarmaja-Korjonen, 2007), thus they were here identified and clumped together as $A$. affinis/quadrangularis ephippia. Total abundances of chydorid carapaces and ephippia (per gram of sediment DM) were also determined. Then, for species-specific reproduction patterns, relative proportions of chydorid carapaces and ephippia of most common species through the core were calculated separately, giving the relative share of species-specific sexual reproduction.

The sediment samples were further analysed for subfossil chironomids, prepared with standard methods (Brooks et al., 2007) and analysed for species composition (Nevalainen and Luoto, 2012) following the identification guides of Wiederholm (1983) and Brooks et al. (2007). Indicator species of chironomids were used to infer the quality of benthic conditions via the benthic quality index (BQI) (Wiederholm, 1980). Profundal benthic macroinvertebrate communities, especially larvae of chironomids, have been often used in the ecological classification and biomonitoring of temperate lakes due to their high indicator value (Luoto, 2011). The BQI is based on a number of indicator taxa and it ranges from a score of one (eutrophic lakes with low benthic quality) to a score of five (oligotrophic lakes with high benthic quality).

Cluster analysis (unweighted pair-group average) was used to illustrate temporal changes in chydorid reproduction (proportions of chydorid carapaces and ephippia). Here, the Bray-Curtis similarity measure was chosen. Additionally, the sample clusters were further verified with the analysis of similarity (ANOSIM), which was run using Bray-Curtis similarity measure and 10,000 permutations. Spearman's rank correlation $\left(\mathrm{r}_{\mathrm{S}}\right)$ and the level of statistical significance $(\mathrm{P})$ were used to estimate relationships between proportions of ephippia of the most abundant ephippial taxa and ecological quality of the lake (BQI and LOI).

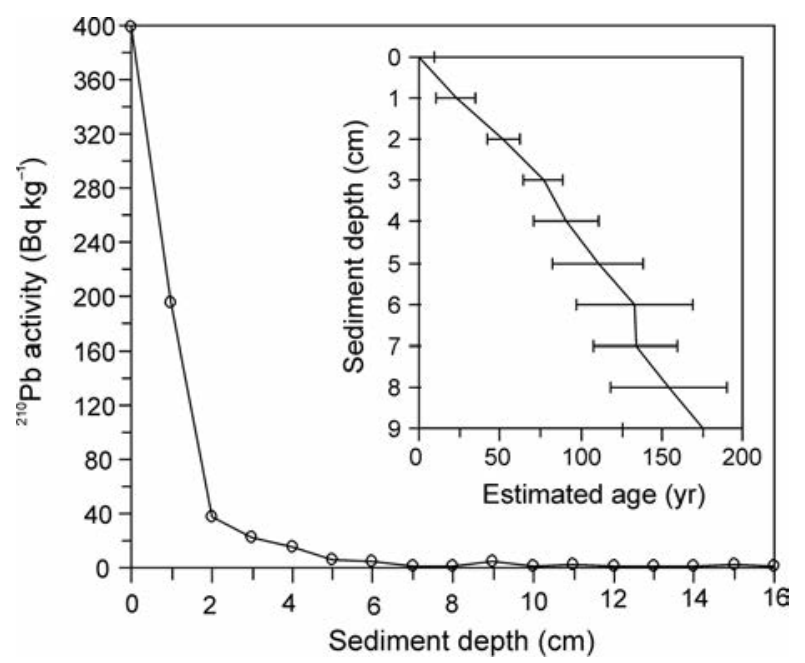

Fig. 2. Total specific ${ }^{210} \mathrm{~Pb}$ activity and constant rate supply (CRS) age-depth model (right above corner) with error estimates of the sediment core from lake Oberer Landschitzsee. 


\section{RESULTS}

The ${ }^{210} \mathrm{~Pb}$ activity and constructed CRS age-depth model suggested that sediment section at $8 \mathrm{~cm}$ corresponded to $\sim 1850 \mathrm{AD}$ and horizons for $1900 \mathrm{AD}$ and 1950 AD were estimated for 5 and $2 \mathrm{~cm}$ depths, respectively (Fig. 2). As the oldest ${ }^{210} \mathrm{~Pb}$-based age estimation was at $9 \mathrm{~cm}(\sim 1830$ AD), age estimations of the samples below this depth were determined through extrapolation and provided an age estimation of $\sim 1700 \mathrm{AD}$ for the bottom of the core (Fig. 3). As the extent of the cold climate period LIA in Central Europe and in the Alps is generally set to around mid- $19^{\text {th }}$ century (Mangini et al., 2005; Vincent et al., 2005; Ivy-Ochs et al., 2009), LIA is assumed to be represented by the lower part of the sediment sequence $(16-8 \mathrm{~cm})$, though the extrapolated age estimations of the lower core should be cautiously interpreted.

Cluster analysis separated the sediment assemblages into three main groups (cut-off value $=0.6$ ) (Fig. 3). Samples of 16-8 cm (until $\sim 1850$ AD), 7-1 cm ( 1850-1950 $\mathrm{AD})$, and $0 \mathrm{~cm}$ (most recent decades) were clustered on the basis of proportions of chydorid carapaces and ephippia and were further used in the zonal division of the stratigraphy (OL1-OL3) (Fig. 3). Significant differences between the sample groups were further tested with the ANOSIM, which resulted in mean ranked distances within and between groups of 33.68 and 93.62, respectively ( $\mathrm{R}=0.88, \mathrm{P}<0.001)$, and suggested significant dissimilarities amongst the sample groups. The post-hoc pairwise comparison suggested that dissimilarities between the sample groups of $16-8 \mathrm{~cm}$ and $7-1 \mathrm{~cm}$ were significant $(\mathrm{P}<0.001)$. When only data of chydorid ephippia was used, significant mean ranked distances within and between groups were 77.37 and 56.21, respectively $(\mathrm{R}=0.31, \mathrm{P}=0.01)$. The pairwise comparison here showed that groups of $16-8 \mathrm{~cm}$ and $7-1 \mathrm{~cm}$ were significant $(\mathrm{P}=0.01)$.

Carapaces of seven chydorid taxa were encountered in the core samples (Fig. 3). Alona affinis (Leydig) and $A$. quadrangularis (Müller) dominated the community until $\sim 1850$ AD (16-8 cm, OL1). Approximately in 1850-1900 AD (OL2), carapaces of $A$. affinis and A. quadrangularis markedly decreased and those of Acroperus harpae (Baird) increased. Simultaneously, Alonella excisa (Fischer) and Chydorus (C.) sphaericus-type (sensu lato) also increased. Alona species increased again in the most recent sediments and Acroperus harpae, Alonella excisa, and C. sphaericus decreased (OL3). Ephippia of all chydorid species (which were encountered as carapaces) were found, but those of C. sphaericus-type, Alona guttata (Sars), and Alonella nana (Baird) were very scarce through the core (Fig. 3). Alona affinis/quadrangularis ephippia were abundant ( 10\%) until 1900 AD and increased up to $20 \%$ between 1900 and 1950 AD. Ephippia of Acroperus harpae were constantly found in zone OL1 and they slightly increased around 1850-1950 AD (OL2). Nevertheless, they decreased again in the most recent sed-

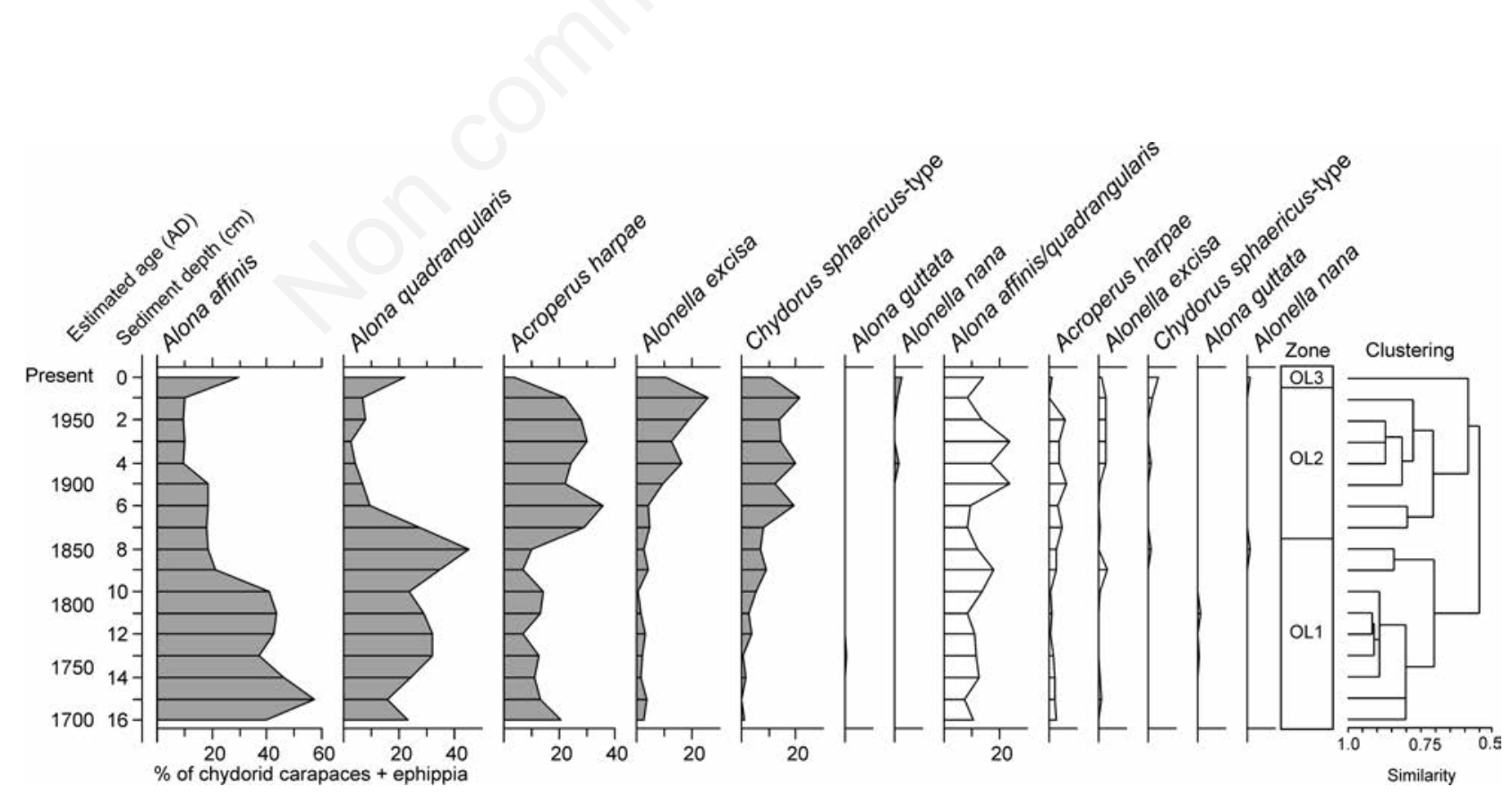

Fig. 3. Relative proportions of chydorid carapaces (gray silhouette) and ephippia (white silhouette) in the Oberer Landschitzsee core. Sample clusters (zones OL1-OL3) are based on unweighted pair-group averages and Bray-Curtis similarity measure. Age estimations of the upper core $(0-9 \mathrm{~cm})$ are based on the age-depth model (Fig. 2$)$ and estimations of the lower core (10-16 cm) are based on the extrapolation of the ages from the upper sediment section. 
iment layers (OL3). Alonella excisa ephippia occurred constantly in low proportions from $\sim 1900$ AD onward.

Chironomid-based BQI (Wiederholm, 1980) showed good benthic quality in the lower section of the core until $\sim 1850 \mathrm{AD}$ (16-8 cm, zone OL1) and decreasing quality after that until late $20^{\text {th }}$ century (Figs. 3 and 4). The BQI slightly increased in the topmost sediment sample (OL3) (Figs. 3 and 4). The organic content of the sediment showed a general increasing trend from the bottom $(\sim 20 \%)$ to the top ( $\sim 30 \%)$ of the core (Fig. 4). The total number of chydorid carapaces peaked in $\sim 1850-1900$ AD and decreased towards the core top. Total abundance of chydorid ephippia was highest (250-320 $\mathrm{g}^{-1} \mathrm{DM}$ ) from 1850 until early $20^{\text {th }}$ century $(7-3 \mathrm{~cm})$ but decreased toward the core top (Fig. 4). The relative proportion of total chydorid ephippia varied between 10 and $30 \%$ in the core, and the highest values observed were around $\sim 1900$ AD (Fig. 4). Proportions of ephippia were individually calculated for the species which had highest counts for carapaces/ephippia through the core: A. affinis/quadrangularis (14-128/830 ) and Acroperus harpae (4-74/0-9). Sexual reproduction of A. affinis/quadrangularis varied between $\sim 10$ and $25 \%$ during LIA but increased up to $>60 \%$ between 1900 and $1950 \mathrm{AD}(5-3 \mathrm{~cm})$ and then decreased down to $20 \%$ in the topmost sample (Fig. 4). Proportions of Acroperus harpae ephippia remained below $20 \%$ for most of the core but there was a peak at $9 \mathrm{~cm}(>25 \%)$ and no ephippia were recovered at $1 \mathrm{~cm}$.

Tab. 1 illustrates the Spearman's correlations between $\mathrm{BQI}$ and LOI and sedimentary chydorid ephippia. Signif- icant negative correlations were found between BQI and proportions of ephippia of Acroperus harpae and Alonella excisa (of the total community). Significant positive correlations existed between LOI and ephippia of Acroperus harpae (of the total community), and proportions of total chydorid ephippia (Tab. 1). Ephippia of A. affinis/quadrangularis (of the total community) had moderate correlations $\left(\mathrm{r}_{\mathrm{S}}=-0.30,0.39\right)$ with $\mathrm{BQI}$ and LOI, respectively, but these relationships were not statically significant. When using proportions of ephippia from the sum of carapaces+ephippia of individual species the relationships between $\mathrm{BQI}$ and LOI and A. affinis/quadrangularis ephippia were strong and significant $\left(\mathrm{r}_{\mathrm{S}}=-0.83,0.74\right.$; $\mathrm{P}<0.001)$.

Tab. 1. Spearman's correlations between benthic quality index, organic matter and sedimentary chydorid ephippia (of the total community/species-specifically). Significant correlations are marked in italics.

\begin{tabular}{lcc}
\hline & BQI & LOI \\
\hline Total chydorid ephippia (\%) & -0.44 & $0.50^{*}$ \\
Total chydorid ephippia (No. $\left.\mathrm{g}^{-1} \mathrm{DM}\right)$ & -0.21 & 0.26 \\
Alona affinis/quadrangularis ephippia (\%) & $-0.30 /-0.83^{* * *}$ & $0.39 / 0.74^{* * *}$ \\
Acroperus harpae ephippia (\%) & $-0.49^{*} /-0.05$ & $0.52^{*} / 0.25$ \\
Alonella excisa ephippia (\%) & $-0.59^{* *} /$ & $0.39 /$ \\
\hline
\end{tabular}

$\overline{B Q I \text {, between benthic quality index; LOI, organic matter; } D M \text {, dry matter. }}$ ${ }^{*} P \leq 0.05 ;{ }^{* *} P \leq 0.01 ;{ }^{* * *} P \leq 0.001$.

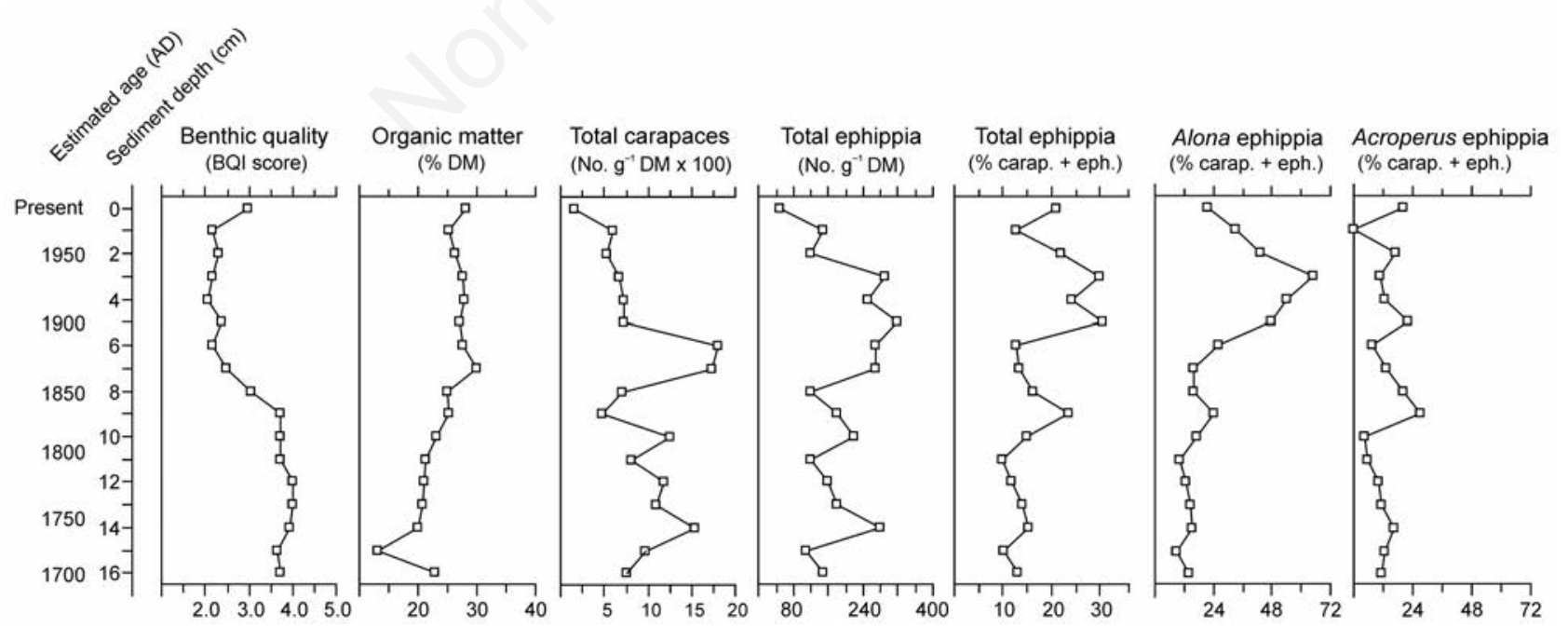

Fig. 4. Benthic quality index (BQI), sediment organic matter, total number of chydorid carapaces and ephippia, percentage of total chydorid ephippia, and proportions of ephippia of Alona affinis/quadrangularis and Acroperus harpae in the Oberer Landschitzsee core. Age estimations of the upper core $(0-9 \mathrm{~cm})$ are based on the age-depth model (Fig. 2$)$ and estimations of the lower core (10-16 cm) are based on the extrapolation of the ages from the upper sediment section. 


\section{DISCUSSION}

\section{Little Ice Age: high benthic quality, until 1850 AD}

In the current study, the fossil chironomid assemblages and organic content of the sediment were utilised to infer long-term variability in the ecological status (i.e. benthic quality and productivity) of lake Oberer Landschitzsee. There exists a long tradition in using macrobenthic invertebrate communities as indicators for lake benthic quality (Brundin, 1949; Sæther, 1979; Wiederholm, 1980), and, accordingly, the chironomid-based BQI values showed that the benthic quality of lake Oberer Landschitzsee was good during the LIA (until $1850 \mathrm{AD}$ ), but started to decline from $1850 \mathrm{AD}$ onward and resulted in poor benthic quality at early $20^{\text {th }}$ century (Fig. 4). In support of this, organic matter of the sediment showed corresponding trends as it was lower during the LIA than in the post-LIA section of the core (Fig. 4). As lake Oberer Landschitzsee is located remotely at high altitude in the Austrian Alps (Fig. 1) and, thus, not subjected to direct anthropogenic influence, its in-lake processes have likely been governed by direct atmospheric forcing. Accordingly, previous paleo-limnological and -climatological investigations on the lake indicated that warm climate periods in the past have been coupled with increased productivity, onset of stratification, and hypolimnetic oxygen deficit (Schmidt et al., 2008). These processes are also closely related to Alpine land-use, which has extended at higher altitudes through periods of ameliorated climate. Thus, the long-term ecological quality of the lake has likely been driven by past climate variability and the high benthic quality and low productivity during the LIA until $\sim 1850 \mathrm{AD}$ may have been related to short open-water season under cold climate conditions (Nevalainen and Luoto, 2012).

The current results (proportions of chydorid carapaces) (Fig. 3) indicated that two benthic Alona species - A. affinis and $A$. quadrangularis - were abundant in lake Oberer Landschitzsee prior to $\sim 1850 \mathrm{AD}$ when the lake had good benthic quality (Fig. 4). This is in accordance with previous knowledge on their high-altitude distribution and ecological preferences in the Alps (Lotter et al., 1997; Bigler et al., 2006; Manca and Armiraglio, 2002; Kamenik et al., 2007; Nevalainen et al., 2011a). Some chydorid species, such as A. affinis and A. quadrangularis, can be defined as true bottom-dwellers inhabiting sediments down to the profundal zone (Fryer, 1968; Flössner, 2000), and thus, they are easily exposed to environmental conditions of their benthic habitats, e.g., oxygen availability. Therefore, it is possible that the prevalence of the two Alonas chydorid in Oberer Landschitzsee was also indicative of their preference for good benthic conditions.

\section{Post-Little Ice Age: declined benthic quality, 1850 to present}

The benthic quality of lake Oberer Landschitzsee started to decline from $1850 \mathrm{AD}$ onward and resulted in poor status during the early $20^{\text {th }}$ century (Fig. 4 ). Correspondingly, organic matter of the sediment has increased from the LIA-section up to now (Fig. 4), which can be attributed to lake productivity (Willemse and Törnqvist, 1999; Nesje and Dahl, 2001; Shuman, 2003). The documented post-LIA climate warming in Austrian Alps (Auer et al., 2007) likely resulted in a longer open-water season causing higher production (increased LOI) (Fig. 4) and possibly reduced profundal oxygen availability due to lake stratification (decreased BQI) (Fig. 4) and increased organic matter (Nevalainen and Luoto, 2012). Following the declining trend in $\mathrm{BQI}$ and increasing trend in LOI (Fig. 4), the abundance of the two Alona species in the community declined severely (Fig. 3) and were replaced in the postLIA period by Acroperus harpae, Alonella excisa, and $C$. sphaericus-type, thus giving evidence for a recent and dramatic community shift in chydorids. This change was further supported by the cluster analysis (Fig. 3) and ANOSIM results that suggested a period of change in assemblages ( $1850 \mathrm{AD})$. The occurrence of Acroperus harpae is usually related to the presence of aquatic vegetation (Fryer, 1968), though it is very frequent in cold lakes across Europe (Brancelj et al., 2009). Hence, its increase in lake Oberer Landschitzsee may be related to higher productivity and development of some aquatic macrophytes (Nevalainen and Luoto, 2012). Additionally, although recognised as counterparts in alpine lakes (Manca and Armiraglio, 2002; Catalan et al., 2009; Nevalainen et al., 2011a), the success of C. sphaericus and Alonella excisa may be associated to post-LIA climate warming and increased productivity. C. sphaericus is known to thrive under nutrient enrichment (Guilizzoni et al., 2012) and Alonella excisa is reportedly associated to milder and more productive conditions (Manca and Armiraglio, 2002; Catalan et al., 2009), which is in accordance with BQI and LOI developments (Fig. 4).

Even though diapause in aquatic invertebrates - including cladocerans - has generally received much attention and is fairly well understood (Alekseev et al., 2007), Frey's (1982) assumption that induction and control factors of gamogenesis are only partially comprehended, pertains even today. The environmental control of gamogenesis and diapause in cladocerans has been investigated since the early $20^{\text {th }}$ century (e.g., Banta, 1925; Banta and Brown, 1929). Subsequently, induction of gamogenesis and formation of diapausing resting eggs in Daphnia were shown to be mainly controlled by climatic factors, such as water temperature and photoperiod length, but also by some density-related factors, such as starvation (Stross and Hill, 1965, 1968; Stross, 1969a, 1969b). More recently, many stressors other than climate have been shown to easily and quickly interact with the induction of gamogenesis, as the influences of food limitation, crowding and pressure from fish predation (Hobæk and 
Larsson, 1990; Larsson, 1991; Kleiven et al., 1992; Ślusarczyk, 1995, 2001; Pijanowska and Stolpe, 1996). Much less attention has been paid to diapause in Chydoridae. However, fragmental studies on natural populations (Kubersky, 1977, Koksvik, 1995, Nevalainen, 2008; Nevalainen and Sarmaja-Korjonen, 2008) and laboratory traits (Shan and Frey, 1968; Shan, 1974) suggest that multiple environmental stressors control the induction, timing, and intensity of gamogenesis and dormant stage.

The paleolimnological approach has offered some valuable information on the patterns and the environmental control of chydorid gamogenesis through the use of total chydorid ephippia (TCE), i.e. the relative proportion of chydorid ephippia from the sum of chydorid carapaces+ephippia in lake sediments (Sarmaja-Korjonen, 2003, 2004). In general, TCE has been interpreted to be related to climate variables, such as length of the openwater season (Sarmaja-Korjonen, 2007; Sarmaja-Korjonen and Seppä, 2007; Luoto et al., 2008) and summer temperatures (Kultti et al., 2011; Nevalainen et al., 2012a). Precisely, it has been assumed to be higher during short open-water season and cold summers. This interpretation is based on the relative length and intensity of both parthenogenetic and gamogenetic reproduction periods because under harsh climate conditions the relative importance of gamogenesis increases and that of parthenogenesis decreases. However, TCE can greatly vary due to increases in ephippia of individual species and, thus, its use in paleoclimatic implications is hampered by other environmental stimuli, e.g. pollution, which may affect gamogenesis of specific species (Nevalainen et al., 2011b, 2011c). The current results from lake Oberer Landschitzsee show that TCE remained relatively stable during LIA (10-15\%), but exhibited two peaks: 1850 AD (20\%) and $\sim 1900-1950$ AD ( 25-30\%), which were mainly driven by increased ephippia of $A$. affinis/quadrangularis (Fig. 3). Thus, it can be suggested that the increased TCE in the post-LIA section of the Oberer Landschitzsee core was impacted by a species-specific response to environmental stressor not attributable to decreased open-water season or summer temperatures, such as benthic quality (Fig. 4; Tab. 1), because general post-1850 AD trends in regional temperatures stand for climate warming (Auer et $a l ., 2007)$. Cluster analysis identified a significant threshold in proportions of carapaces and ephippia at around $1850 \mathrm{AD}$ that was further evidenced by ANOSIM, which indicated significant differences in assemblages of chydorid ephippia between zones OL1 and OL2 (16-8 and 7-1 cm) (Fig. 3).

In addition to ephippia of $A$. affinis/quadrangularis, those of Acroperus harpae and Alonella excisa increased in the post-LIA period (Fig. 3) and correlated with the ecological quality of lake Oberer Landschitzsee (Tab. 1). However, as Acroperus harpae and Alonella excisa in- creased in the community (as indicated by their carapaces), we can assume that the possibility of encountering their ephippia also increased and, accordingly, their ephippia became more abundant in the core. This development strongly contradicts the abundance of carapaces of the two Alonas as they dramatically decreased from 1850 AD onward, but yet their ephippia increased. Thus, apparently, $A$. affinis and $A$. quadrangularis were most impacted by the environmental change. Therefore, the current results suggest that the sexual reproduction of the two declining Alona species exhibited an increase in the post-LIA sediment section around 1900-1950 AD, which was indicated by a markedly increased proportion (from 10-20 up to $60 \%$ ) of their ephippia (Fig. 4). This change strongly corresponded with the period of declined benthic quality and increased organic matter in the sediment (Fig. 4, Tab. 1). This implies that the increased productivity and deteriorated benthic quality in lake Oberer Landschitzsee may have resulted in intensified sexual reproduction of the two Alona species. As diapause is used as a mechanism to avoid unfavourable environmental conditions (Frey 1982), low benthic quality (e.g., low oxygen availability in summer) might result in intensified gamogenesis. This in turn results in high abundance of diapausing resting eggs since oxygen availability is crucial for the survival of benthic animals. Accordingly, the current results appear to support our hypothesis that a population with low probability for survival as active individuals through a period of unfavourable environmental conditions reproduce with high sexual intensity in order to lay a considerable amount of dormant resting eggs.

Clustering of samples showed that the most recent assemblage (zone OL3) of chydorid carapaces and ephippia diverged from previous samples (Fig. 3) and this divergence was supported by ANOSIM, although the pairwise comparison between the sample groups $7-1 \mathrm{~cm}$ and $0 \mathrm{~cm}$ did not result in significant differences. The topmost sediment sample suggested that the community bounced back toward LIA conditions and that ephippia of $A$. affinis/quadrangularis decreased to values comparable to those of the LIA period (Figs. 3 and 4). The community and reproductive shift occurred again alongside with improved benthic quality (Figs. 3 and 4; Tab. 1). Thus, it is possible that the late $20^{\text {th }}$ century stepwise and high-magnitude increase in temperatures, which is documented in a regional instrumental temperature series (Auer et al., 2007), caused a breakage of summer stratification, thus improving benthic conditions (Nevalainen and Luoto, 2012) and, accordingly, the observed community and reproduction rebound. Currently, the water column of lake Oberer Landshcitzsee during summer time is not strongly stratified and the hypolimnion is well oxygenated (see Methods section above).

Since chydorid gamogenesis has not been studied intensively, earlier documentations on gamogenetic behav- 
iour of individual chydorid species are almost non-existing. The paleolimnological records from Finland have however caught up signals of increased gamogenesis in A. affinis during periods of environmental stress related to altered limnological conditions and food-web changes (Sarmaja-Korjonen, 2003; Nevalainen et al., 2011c). In addition, increased gamogenesis of Alonella nana has been detected from sedimentary archives and has been related to eutrophication (Nevalainen et al., 2011b). On the basis of the current results, it seems appropriate to suggest that benthic $A$. affinis and $A$. quadrangularis may intensify their gamogenesis to guarantee successful diapause and/or increase genetic variability for survival under altered limnological ranges. As the intensity of gamogenesis may vary considerably among populations of Daphnia (Cáceres and Tessier, 2004) and chydorids (Frey, 1982; Nevalainen and Sarmaja-Korjonen, 2008), it is likely that the archive of subfossil ephippia in lake Oberer Landschitzsee is indicative of an intensified sexual reproduction of local populations to meet and adapt to new environmental conditions.

\section{CONCLUSIONS}

The present results show that paleolimnological records of chydorid microfossils may be utilised to seek answers to particular ecological phenomena. The results also imply that subfossil chydorid assemblages and ephippia may give indications on the ecological quality of the lake ecosystems and, thus, may be used as additional proxies in future assessments of lake ecological status. Furthermore, some ecological phenomena, such as reproductive behaviour of cladocerans which are difficult and demanding to detect and quantify via the neolimnological approach, can be reliably distinguished from the paleolimnological archives. Thus, the paleolimnological approach should not be segregated from aquatic ecology, but rather seen as a promising tool for detecting long-term ecological trends for understanding general ecological phenomena.

\section{ACKNOWLEDGMENTS}

The authors are grateful to Hannes Höllerer, Rainer Kurmayer, Thomas Weisse, and Ulrike Koll, who helped with the field work, and Johann Knoll, who prepared the sediment samples for microfossil analyses. The authors would also like to thank Rainer Kurmayer for providing the limnological data. The two anonymous reviewers for their constructive comments on the manuscript are gratefully acknowledged.

This study is a contribution to projects EGGER (Kone Foundation, personal grant for L. Nevalainen), ILMAVEIVI (Academy of Finland, personal grant \#250343 for T.P. Luoto), and DETECTIVE (Austrian Academy of Sciences, Nationalkomitee Alpenforschung).

\section{REFERENCES}

Alekseev VR, DeStasio B, Gilbert JJ (eds.), 2007. Diapause in aquatic invertebrates: theory and human use. Springer, Dordrecht.

Appleby PG, 2001. Chronostratigraphic techniques in recent sediments, p. 171-203. In: W.M. Last and J.P. Smol (eds.), Tracking environmental changes using lake sediments. Vol. 1: basin analysis, coring, and chronological techniques. Kluwer Academic Publ., Dordrecht.

Auer I, Böhm R, Jurkovic A, Lipa W, Orlik A, Potzmann R, Schöner W, Ungersböck M, Matulla C, Briffa K, Jones PD, Efthymiadis D, Brunetti M, Nanni T, Maugeri M, Mercalli L, Mestre O, Moisselin JM, Begert M, Müller-Westermeier G, Kveton V, Bochnicek O, Stastny P, Lapin M, Szalai S, Szentimrey T, Cegnar T, Dolinar M, Gajic-Capka M, Zaninovic K, Majstorovic Z, Nieplova E, 2007. HISTALP - Historical instrumental climatological surface time series of the greater Alpine region 1760-2003. Int. J. Climatol. 27:17-46.

Banta AM, 1925. The relation between sexual reproduction and the production of male offspring in Moina macrocopa. Am. Nat. 59:50-61.

Banta AM, Brown LA, 1929. Control of sex in Cladocera. III. Localization of the critical period for control of sex. Proc. Natl. Acad. Sci. USA 15:71-81.

Bigler C, Heiri O, Krškova R, Lotter A, Sturm M, 2006. Distribution of diatoms, chironomids and cladocera in surface sediments of thirty mountain lakes in south-eastern Switzerland. Aquat. Sci. 68:154-171.

Binford MW, 1986. Ecological correlates of net accumulation rates of Cladocera remains in lake sediments. Hydrobiologia 143:123-128.

Bjerring R, Becares E, Declerck S, Gross EM, Hansson L-A, Kairesalo T, Nykänen M, Halkiewicz A, Kornijów R, Conde-Porcuna JM, Seferlis M, Nõges T, Moss B, Amsinck SL, vad Odgaard B, Jeppesen E, 2009. Subfossil Cladocera in relation to contemporary environmental variables in 54 Pan-European lakes. Freshwater Biol. 54:2401-2417.

Brancelj A, Kernan M, Jeppesen E, Rautio M, Manca M, Šiško M, Alonso M, Stuhlík E, 2009. Cladocera remains from the sediments of remote cold lakes: a study of 294 lakes across Europe. Adv. Limnol. 62:269-294.

Brooks SJ, Langdon PG, Heiri O, 2007. The identification and use of Palaearctic Chironomidae larvae in palaeoecology. QRA Technical Guide No. 10. Quaternary Research Association ed., London.

Brundin L, 1949. Chironomiden und andere Bodentiere der südschwedischen Urgebirgseen. [Article in German] Rep. Inst. Freshwat. Res. Drottningholm 30:1-194.

Cáceres CE, Tessier AJ, 2004. Incidence of diapause varies among populations of Daphnia pulicaria. Oecologia 141: 425-431.

Catalan J, Barbieri MG, Bartumeus F, Bitušík P, Botev I, Brancelj A, Cogălniceanu D, Manca M, Marchetto A, Ognjanova-Rumenova N, Pla S, Rieradevall M, Sorvari S, Štefková E, Stuchlík E, Ventura M, 2009. Ecological thresholds in European alpine lakes. Freshwater Biol. 54:2494-2517.

Dean WE, 1974. Determination of carbonate and organic matter in calcareous sediments and sedimentary rocks by loss on ignition: comparison with other methods. J. Sediment. Petrol. 44:242-248. 
Flössner D, 2000. Die Haplopoda und Cladocera (ohne Bosminidae) Mitteleuropas. [Book in German]. Backhuys Publ., Leiden: 428 pp.

Flynn WW, 1968. The determination of low-levels of polonium210 in environmental materials. Anal. Chim. Acta 43:221222.

Frey DG, 1959. The taxonomic and phylogenetic significance of the head pores of the Chydoridae (Cladocera). Int. Rev. Ges. Hydrobio. 44:27-50.

Frey DG, 1960. The ecological significance of cladoceran remains in lake sediments. Ecology 41:684-699.

Frey DG, 1962. Supplement to: The taxonomic and phylogenetic significance of the head pores of the Chydoridae (Cladocera). Int. Rev. Ges. Hydrobio. 47:603-609.

Frey DG, 1982. Contrasting strategies of gamogenesis in northern and southern populations of Cladocera. Ecology 63:223241.

Fryer G, 1968. Evolution and adaptive radiation in the Chydoridae (Crustacea: Cladocera): A study in comparative functional morphology and ecology. Philos. T. Roy. Soc. B 254:221-385.

Guilizzoni P, Levine SN, Manca M, Marchetto A, Lami A, Ambrosetti W, Brauer A, Gerli S, Carrara EA, Rolla A, Guzzella L, Vignati DAL, 2012. Ecological effects of multiple stressors on a deep lake (Lago Maggiore, Italy) integrating neo and palaeolimnological approaches. J. Limnol. 71:1-22.

Hobæk A, Larsson P, 1990. Sex determination in Daphnia magna. Ecology 71:2255-2268.

Ivy-Ochs S, Kerschner H, Maisch M, Christl M, Kubik PW, Sclüchter C, 2009. Latest Pleistocene and Holocene glacier variations in the European Alps. Quaternary Sci. Rev. 28:2137-2149.

Jeppesen E, Leavitt P, De Meester L, Jensen JP, 2001. Functional ecology and palaeolimnology: using cladoceran remains to reconstruct anthropogenic impact. Trends Ecol. Evol. 16:191-198.

Jeppesen E, Nõges P, Davidson TA, Haberman J, Nõges T, Blank K, Lauridsen TL, Søndergaard M, Sayer CD, Laugaste R, Johansson LS, Bjerring R, Amsinck SL, 2011. Zooplankton as indicators in lakes: a scientific-based plea for including zooplankton in the ecological quality assessment of lakes according to the European Water Framework Directive (WFD). Hydrobiologia 676:279-297.

Kamenik C, Szeroczyńska K, Schmidt R, 2007. Relationship among recent Alpine Cladocera remains and their environment: implications for climate-change studies. Hydrobiologia 594:33-46.

Kattel GR, Battarbee RW, Mackay A, Birks HJB, 2007. Are cladoceran fossils in lake sediment samples a biased reflection of the communities from which they are derived? J. Paleolimnol. 38:157-181.

Kiser RV, Donaldson JR, Olson PR, 1963. The effect of rotenone on zooplankton populations in freshwater lakes. T. Am. Fish. Soc. 92:17-24.

Kleiven OT, Larsson P, Hobæk A, 1992. Sexual reproduction in Daphnia magna requires three stimuli. Oikos 65:197-206.

Koksvik JI, 1995. Seasonal occurence and diel locomotor activity in littoral Cladocera in a mesohumic lake in Norway. Hydrobiologia 307:193-201.

Kubersky ES, 1977. Worldwide distribution and ecology of
Alonopsis (Cladocera: Chydoridae) with a description of Alonopsis americana sp. nov. Int. Rev. Ges. Hydrobio. 62:649-685.

Kultti S, Nevalainen L, Luoto TP, Sarmaja-Korjonen K, 2011. Subfossil chydorid (Cladocera, Chydoridae) ephippia as paleoenvironmental proxies - Evidence from boreal and subarctic lakes in Finland. Hydrobiologia 676:23-37.

Larsson P, 1991. Intraspecific variability in response to stimuli for male and ephippia formation in Daphnia pulex. Hydrobiologia 225:281-290.

Lotter AF, Birks HJB, Hofmann W, Marchetto A, 1997. Modern diatom, Cladocera, Chironomid, and Chrysophyte cyst assemblages as quantitative indicators for the reconstruction of past environmental conditions in the Alps. I. Climate. J. Paleolimnol. 18:395-420.

Lotter AF, Birks HJB, Hofmann W, Marchetto A, 1998. Modern diatom, Cladocera, Chironomid, and Chrysophyte cyst assemblages as quantitative indicators for the reconstruction of past environmental conditions in the Alps. II. Nutrients. J. Paleolimnol. 19:443-463.

Luoto TP, 2011. Indicator value of midge larvae (Diptera: Nematocera) in shallow boreal lakes with a focus on habitat, water quality, and climate. Aquat. Insect. 33:351-370.

Luoto TP, Nevalainen L, Sarmaja-Korjonen K, 2008. Multiproxy evidence for the 'Little Ice Age' from Lake Hampträsk, Southern Finland. J. Paleolimnol. 40:1097-1113.

Manca M, Armiraglio M, 2002. Zooplankton of 15 lakes in the Southern Central Alps: comparison of recent and past (preca 1850 AD) communities. J. Limnol. 61:225-231.

Manca M, Torretta B, Comoli P, Amsinck SL, Jeppesen E, 2007. Major changes in trophic dynamics in large, deep sub-alpine Lake Maggiore from 1940s to 2002: a high resolution comparative palaeo-neolimnological study. Freshwater Biol. 52:2256-2269.

Mangini A, Spötl C, Verdes P, 2005 Reconstruction of temperature in the Central Alps during the past $2000 \mathrm{yr}$ from a $\delta^{18} \mathrm{O}$ stalagmite record. Earth Planet. Sc. Lett. 235:741-751.

Nesje A, Dahl SO, 2001. The Greenland 8200 cal. yr BP event detected in loss-on-ignition profiles in Norwegian lacustrine sediment sequences. J. Quaternary Sci. 16:155-166.

Nevalainen L, 2008. Parthenogenesis and gamogenesis in seasonal succession of chydorids (Crustacea, Chydoridae) in three low-productive lakes as observed with activity traps. Pol. J. Ecol. 56:85-97.

Nevalainen L, 2010. Evaluation of microcrustacean (Cladocera, Chydoridae) biodiversity based on sweep net and surface sediment samples. Ecoscience 17:356-364.

Nevalainen L, 2011. Intra-lake heterogeneity of sedimentary cladoceran (Crustacea) assemblages forced by local hydrology. Hydrobiologia 676:9-22.

Nevalainen L, 2012. Distribution of benthic microcrustaceans along a water depth gradient in an Austrian Alpine lake Sedimentary evidence for niche separation. Limnologica 42:65-71.

Nevalainen L, Luoto TP, 2012. Faunal (Chironomidae, Cladocera) responses to post-Little Ice Age climate warming in the high Austrian Alps. J. Paleolimnol. 48:711-724.

Nevalainen L, Luoto TP, Kultti S, Sarmaja-Korjonen K, 2012a. Do subfossil Cladocera and chydorid ephippia disentangle Holocene climate trends? Holocene 22:291-299. 
Nevalainen L, Luoto TP, Levine S, Manca M, 2011a. Modern and pre-Industrial Age distributions of Cladocera in Italian and Swiss Alpine lakes. Hydrobiologia 676:173-185.

Nevalainen L, Sarmaja-Korjonen K, 2008. Intensity of autumnal gamogenesis in chydorid (Cladocera, Chydoridae) communities in southern Finland, with a focus on Alonella nana (Baird). Aquat. Ecol. 42:151-163.

Nevalainen L, Sarmaja-Korjonen K, Gąsiorowski M, Luoto TP, $2011 \mathrm{~b}$. Late $20^{\text {th }}$ century shifts in cladoceran community structure and reproduction in a boreal acidified lake. Fund. Appl. Limnol. 179:81-92.

Nevalainen L, Sarmaja-Korjonen K, Luoto TP, Kultti S, 2011c. Does oxygen availability regulate sexual reproduction in local populations of the littoral cladoceran Alonella nana? Hydrobiologia 661:463-468.

Nevalainen L, Van Damme K, Luoto TP, Salonen V, 2012b. Fossil remains of an unknown Alona species (Chydoridae, Aloninae) from a high arctic lake in Nordaustlandet (Svalbard) in relation to glaciation and Holocene environmental history. Polar Biol. 35:325-333.

Pijanowska J, Stolpe G, 1996. Summer diapause in Daphnia as a reaction to the presence of fish. J. Plankton Res. 18:14071412.

Rautio M, 2007. The use of Cladocera in paleolimnology, p. 2031-2039. In: S.A. Elias (ed.), Encyclopedia of Quaternary Sciences. Elsevier, Amsterdam.

Sæther OA, 1979. Chironomid communities as water quality indicators. Holarctic Ecol. 2:65-74.

Sarmaja-Korjonen K, 2003. Chydorid ephippia as indicators of environmental change- biostratigraphical evidence from two lakes in southern Finland. Holocene 13:691-700.

Sarmaja-Korjonen K, 2004. Chydorid ephippia as indicators of past environmental changes - a new method. Hydrobiologia 526:129-136.

Sarmaja-Korjonen K, 2007. Sexual reproduction of chydorids (Anomopoda, Chydoridae) as indicators of climate in recent sediment of Lake Aitajärvi, northern Finnish Lapland. Studia Quaternaria 24:69-72.

Sarmaja-Korjonen K, Seppä H, 2007. Abrubt and consistent responses of aquatic and terrestrial ecosystems to the $8200 \mathrm{cal}$. yr cold event: A lacustrine record from Lake Arapisto, Finland. Holocene 17:457-467.

Sarmaja-Korjonen K, Hakojärvi M, Korhola A, 2000. Subfossil remains of an unknown chydorid (Anomopoda: Chydoridae) from Finland. Hydrobiologia 436:165-169.

Sayer CD, Davidson T, Jones JI, Langdon PG, 2010. Combining contemporary ecology and palaeolimnology to understand shallow lake ecosystem change. Freshwater Biol. 55:487499.

Schmidt R, Roth M, Tessadri R, Weckström K, 2008. Disentan- gling late-Holocene climate and land use impacts on an $\mathrm{Au}-$ trian alpine lake using seasonal temperature anomalies, icecover, sedimentology, and pollen tracers. J. Paleolimnol. 40:453-469.

Shan RK, 1974. Reproduction in laboratory stocks of Pleuroxus (Chydoridae, Cladocera) under the influence of photoperiod and light intensity. Int. Rev. Ges. Hydrobio. 59:643-666.

Shan RK, Frey DG, 1968. Induced interbreeding between two stocks of a chydorid cladoceran. Bioscience 18:203-205.

Shuman B, 2003. Controls on loss-on-ignition variation in cores from two shallow lakes in the northeastern United States. J. Paleolimnol. 30:371-385.

Ślusarczyk M, 1995. Predator-induced diapause in Daphnia. Ecology 76:1008-1013.

Ślusarczyk M, 2001. Food threshold for diapause in Daphnia under the threat of fish predation. Ecology 82:1089-1096.

Smol JP, 1991. Are we building enough bridges between paleolimnology and aquatic ecology? Hydrobiologia 214:201206.

Stross RG, 1969a. Photoperiod control of diapause in Daphnia. II. Induction of winter diapause in the Arctic. Biol. Bull. 136:264-273.

Stross RG, 1969b. Photoperiod control of diapause in Daphnia. III. Two-stimulus control of long-day, short-day induction. Biol. Bull. 137:359-374.

Stross RG, Hill JC, 1965. Diapause induction in Daphnia requires two stimuli. Science 150:1462-1464.

Stross RG, Hill JC, 1968. Photoperiod control of winter diapause in the fresh-water crustacean, Daphnia. Biol. Bull. 134:176198.

Szeroczyńska K, Sarmaja-Korjonen K, 2007. Atlas of subfossil Cladocera from central and northern Europe. Friends of the Lower Vistula Society ed., Świecie: 84 pp.

Vincent C, Le Meur E, Six D, 2005. Solving the paradox of the end of the Little Ice Age in the Alps. Geophys. Res. Lett. 32:L09706.

von Gunten L, Heiri O, Bigler C, van Leeuwen J, Casty C, Lotter AF, Sturm M, 2008. Seasonal temperatures for the past $\sim 400$ years reconstructed from diatom and chironomid assemblages in a high-altitude lake (Lej da la Tscheppa, Switzerland). J. Paleolimnol. 39:283-299.

Wiederholm T, 1980. The use of benthos in lake monitoring. J. Water Pollut. Con. F. 52:537-543.

Wiederholm T, 1983. Chironomidae of the Holarctic region: keys and diagnoses. Vol 1. Larvae. Entomol. Scand. Suppl. 19:1-457.

Willemse NW, Törnqvist TE, 1999. Holocene century-scale temperature variability from West Greenland lake records. Geology 27:580-584. 